\title{
Cloud Agoras: When Blockchain Technology Meets Arendt's Virtual Public Spaces
}

\author{
Dora Kostakopoulou
}

\begin{abstract}
While developments in information technology have always sparked lively debates about democratic participation and citizenship, the advent of blockchain technology promises to change the concept and nature of participatory citizenship by providing an inclusive, secure and transparent mechanism of data sharing among an unlimited number of members. Liav Orgad has written a powerful contribution about the promise of blockchain technology. I fully share his thoughts and his optimism. Blockchain participants are able to interact, share information, collaborate and have access to an incredible amount of information organised in blocks without the intervention of a centralised authority and without any reliance on a centralised platform. More importantly, everyone's copy of the distributed database will be kept updated and will be immutable; information can be added by any member of the global network, but cannot be deleted. Blockchain is thus a platform for worldwide information sharing, interaction and collaboration. As such, it has the potential to enhance political participation, trigger civic mobilisation and to provide the substratum for public action on a global scale.
\end{abstract}

Such a bottom up, participatory and size-neutral (the network could consist of billions of people) digital network does not merely offer a glimpse of what might be possible in terms of global citizenship but, as Liav Orgad has explained, casts doubts on any arguments about the impossibility of global citizenship. This is because blockchain simply removes three of the main obstacles for its realisation; namely, the impermeability of state borders, the size of the demos, and certain costs associated with political participation. Participants just need to have internet access in order to join a network comprising millions of citizens from diverse regions and remote locations of the globe who could be mobilised in influencing public policies and taking part in public actions.

In what follows, I will thus sidestep questions about the feasibility of global citizenship in order to examine how the new technological revolution will lead to innovations in political life and will create Hannah Arendt's public spaces of 'virtual' citizenship. By so doing, I take it for granted that 
blockchain is a 'game-changer' and that it could have significant transformative effects on societies, politics and citizenship. I use the verb 'could' because I do not wish to embrace determinism or to imply the existence of a causal relation between technology and political processes. Blockchain has the potential to transform the way we think about public spaces, citizenship and political participation, but this potential can only be realised if technology is put to uses which can enhance democratic political processes.

My critics might object here that we do not need technological advancements in order to procure new conceptions of public space. Analyses informed by the thinking of philosophers, such as Henri Lefebvre, and geographers, such as Doreen Massey and Edward Soja, have highlighted that spaces are not given but are constructed in different ways by politics and discursive practices. Readers might recall Peter Maier's anthology on the changing boundaries of the political in the late 1980s. ${ }^{1}$ In it, Maier mapped the blurring of the distinction between the state and civil society, while a few years later, Gilles Deleuze commented on the shifting of borders and the proliferation of political spaces within contemporary societies of control. ${ }^{2}$

While all this is true, blockchain promises to realise those ideas in unprecedented ways. It also holds the promise of generating huge publics beyond (and across) geographical borders and territorially defined communities and thus of opening up new citizenship spaces. Rainer Bauböck and Peter Spiro have noted this in their contributions. Citizenship relies on the existence of public spaces of communication, of exchange of ideas, arguments and contested viewpoints and of joint decision-making. For a significant period of time, the agoras of the direct democratic experimentation in ancient Athens became remnants of a distant past that had no chance to be replicated in the present and future. Now, virtual agoras 'containing' millions of active and activist individuals can be built onto blockchain. ${ }^{3}$ The mythical space of a distant past becomes connected with, and re-enacted within, the contemporary world of an embodied digital network that makes citizenship a network good. ${ }^{4}$

Maier, C. C. (ed.) (1987), The Changing Boundaries of the Political.

Cambridge: Cambridge University Press.

2 Deleuze, G. (1992), 'Postscript on the Societies of Control', MIT Press October 59: 3-7. Available at http://www.jstor.org/stable/778828.

3 Isin, E. \& M. Saward (2013), Enacting European Citizenship. Cambridge: Cambridge University Press.

4 Kostakopoulou, D. (2008), The Future Governance of Citizenship. Cambridge: Cambridge University Press, 107-110. 
This is essentially the realisation of Hannah Arendt's conception of 'virtual' public spaces. Virtual 'agoras' built on blockchain will become shared common worlds of continuous flows of speech and action, that is, spaces where people would recognise one another as equals or at least equally entitled to express their views, to 'deal only with one's peers' and to decide on common actions at national, international and global levels. ${ }^{5}$ As Arendt had eloquently noted, the (public) space of speech and action 'can find its proper location almost any time and anywhere' ${ }^{6}$ By transcending topological as well as institutional accounts of the 'public space', blockchain technology not only lends credence to Arendt's conception of public space, but it also promises to open up decentralised public spaces in which all participants can be contributors, deciders and holders of institutional memories. The participants' geographical location does not matter. In an unprecedented bordertranscending move, new spaces of citizenship appear 'almost any time and anywhere' as Arendt had argued. What ties all the blockchain participants together in the virtual public space of citizenship is simply their ongoing concern and active engagement. ${ }^{7}$ These are, in reality, the characteristics that sustain all communities, be they virtual or not: members are visibly concerned about the common state of affairs and want their claims, needs, and aspirations to be heard.

This development can bring about a complete reconceptualisation of the nature of international society; non-statist ways of defining it will gain prominence. Hedley Bull's envisaged transformation of international society from a society of states to a society of peoples will be progressively realised. ${ }^{8}$ Cloud agoras will also prompt a rethinking of communitarian ways of defining communities and international society which see society and culture as interlocked. This is because they do not rely on some form of cultural homogeneity or conformity to a majority's ideas and narratives; the rely, instead, on the coming together of strangers ${ }^{9}$ in order to share their concerns and information, express their interests, make demands on the political system and to articulate proposals for common action. All this is bound to give rise to interesting questions about ways of constructing political order and legitimacy in international relations and politics.

Arendt, H. (1958), The Human Condition. Chicago: Chicago University Press. Above n. 5, at 198.

Kostakopoulou, D. (1996), 'Towards a Theory of Constructive Citizenship in Europe', Journal of Political Philosophy 4 (4): 337-358.

8 Bull, H. (1977), The Anarchical Society. London: Macmillan.

9 Young, I. M. (1986), 'The Ideal of Community and the Politics of Difference', Social Theory and Practice 12 (1): 1-26, at 21-23. 
While cloud agoras have the potential of dislocating citizenship from its statist reference point and stimulating citizen involvement by delivering the affirmative requirements for an active citizenry, namely, information sharing, the exchange of ideas and preferences, capability for action and the means of exerting influence and pressure, they will not be able to resolve the 'problem of equality of voice'. Claude Lefort, Nancy Fraser, Jürgen Habermas and others have commented on the inequalities that persist in democratic public spheres. Some voices will be louder and more influential than others and women will always struggle to find time to engage even virtually. Socio-economic disparities measured in terms of education, income and occupation will also allow certain participants to easily convert their possessed resources into political involvement. The cognitive and linguistic skills for political articulations and activity are not uniformly distributed. Nor do they exist independently of individuals' socio-economic setting and geographical location across the globe. Peter Spiro, Lea Yip and Stefania Milan correctly highlight this problem. Cloud agoras therefore will not be able to transcend the difficulties of ensuring full inclusion in the open public grid. They will certainly be more inclusionary that the existing publics, but they will still represent a stratified model of political community or public space(s). They will also have their own 'spinners', exploiters and manipulators of public opinion. I recall Jean Mansbridge's observations about the dark world of domination and manufactured invisibility of actors underpinning deliberative democracy. ${ }^{10}$

Although it is true that participatory parity cannot be easily achieved even in cloud agoras, it is equally true that the common world of citizenship beyond borders, states and nations could be more activist. And this is good news for democracy in general. It would be relatively easy for millions of blockchain members to mobilise on specific issues and to demand change in law and policy regionally, nationally and globally. It would also be more difficult for decision-making elites to ignore the voices of so many people and to pretend that they do not count or that their claims do not matter. Civic awakenings and political mobilisations in cloud agoras are also likely to exert influence on other public spaces that are more conventional and delineated across national and statist lines. For the boundaries of public spaces, virtual and non-virtual ones, will always be porous and issues will leak from one domain to another. The dawn of global citizenship will thus be a combination of the activation of an international or global society and of a more activist citizenship. Virtual global citizenship promises to be more virtual, in

10 Mansbridge, J. (1995), 'Does Participation Make Better Citizens?', The Good Society 5 (2): 1-7. 
the republican sense; citizens will continually question aspects of public life, make public disclosures of wrongdoing, take an active part in public affairs and engage in regular, assertive action.

That this is good news for citizenship, democracy and politics in general cannot be denied. The virtual public space of blockchain communities will make citizens think, engage and act more virtually. In other words, the virtual reality of cloud agoras will have an impact on institutions and the participants themselves; it will yield pressures for more open, transparent and accountable institutions and will result in more virtuous, that is, actively engaged, citizens. Whether cloud agoras will prove to be decisive public spaces and strong promoters of democratic processes that make wealth, power and privilege accountable or merely subaltern counter publics will depend on the intentions and actions of their participants. In other words, the answer to the question whether the virtual public space of global citizenship will have a decisive influence on global, regional and national public policymaking is not theoretical or scholarly; it will be a contextual one.

Open Access This chapter is licensed under the terms of the Creative Commons Attribution 4.0 International License (http://creativecommons.org/licenses/by/4.0/), which permits use, sharing, adaptation, distribution and reproduction in any medium or format, as long as you give appropriate credit to the original author(s) and the source, provide a link to the Creative Commons license and indicate if changes were made.

The images or other third party material in this chapter are included in the chapter's Creative Commons license, unless indicated otherwise in a credit line to the material. If material is not included in the chapter's Creative Commons license and your intended use is not permitted by statutory regulation or exceeds the permitted use, you will need to obtain permission directly from the copyright holder.

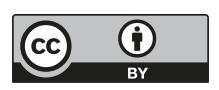

